\title{
Maturity and Maturity Models in Lean Construction
}

Claus Nesensohn, David Bryde, Edward Ochieng and Damian Fearon,

(Liverpool John Moores University, UK)

\begin{abstract}
In recent years there has been an increasing interest in maturity models in managementrelated disciplines; which reflects a growing recognition that becoming more mature and having a model to guide the route to maturity can help organisations in managing major transformational change. Lean Construction (LC) is an increasingly important improvement approach that organisations seek to embed. This study explores how to apply the maturity models to LC. Hence the attitudes, opinions and experiences of key industry informants with high levels of knowledge of LC were investigated. To achieve this, a review of maturity models was conducted, and data for the analysis was collected through a sequential process involving three methods. First a group interview with seven key informants. Second a follow up discussion with the same individuals to investigate some of the issues raised in more depth. Third an online discussion held via Linkedln in which members shared their views on some of the results. Overall, we found that there is a lack of common understanding as to what maturity means in LC, though there is general agreement that the concept of maturity is a suitable one to reflect the path of evolution for LC within organisations.
\end{abstract}

Keywords: Lean Construction maturity, Maturity models, Lean enterprise self-assessment tool, Construction, Project management.

\section{Introduction}

Recent developments in the field of maturity models (MMs) have indicated the need and opportunity to develop MMs for the Lean approach. In 2010, Perkins et al. published a paper in which they described the development of a MM for Lean in the aerospace industry at the Massachusetts Institute of Technology (MIT). This specific assessment tool, the Lean Enterprise Self-Assessment Tool (LESAT), claims to provide an understanding of the current organisational maturity (Leanness) and guide the transformation towards a more lean enterprise. Research has consistently shown that several industries applied MMs to effectively implement a change strategy and to assess the state of maturity in terms of a discipline or strategy (Huat and Low 1994, Perkins et al. 2010). In another major study, Amaratunga et al. (2002) found recognition in the construction sector that MMs are potentially useful. Work in relation to MMs in construction includes the development of the Standardised Process Improvement for Construction Enterprises (SPICE) model (Sarshar et al. 1999). It is further claimed that such models support organisations through setting directions, prioritising improvement actions, and initiating cultural change (Pennypacker 2005). Hence MMs are a well-established concept within many industries and management disciplines.

One type of potentially radical organisational change being undertaken in parts of the construction sector is the implementation of Lean Construction (LC) principles (McGrathChamp and Rosewarne 2009), - in whatever way LC is conceptualised and operationalised by individual companies (Sage et al. 2012). In order to effectively deliver projects using LC, organisations have to develop new ways of thinking and integrate elements of production management and project management into a holistic system for construction (Koskela and Ballard 2012). In addition it is argued that LC often needs changes to the organisational 
culture and its people (Green et al. 2008). According to Nesensohn et al. (2013), the transformation towards LC requires long-term and deep-rooted cultural change; to embed a Lean philosophy as an integral part of how the organisation operates. Despite the current challenges in embedding LC within the industry, it is fairly well understood and has many advocates within the industry and the academic community.

The current debate in LC is linking to performance measurements and non-financial KPIs to support the transformation of LC (Sarhan and Fox 2013). However, very few, if any, authors have been able to draw on any research into the opinions of key informants about how to apply the concept of 'maturity' to LC. Specifically, there is a need to understand whether the concept of MMs, widely adopted in many industries but less so in construction, with the notable exception of SPICE, has a useful role in relation to LC. Furthermore there have been calls in the literature for further work in terms of exploring synergies between MMs and LC, see Nesensohn et al. (2013b), and this paper responds to this call. In doing so it seeks to enhance understanding of MMs amongst key industry informants in a LC context. Moreover it adds to the body of knowledge by reporting on empirical study of practitioner reflections which can help inform and develop new theory.

\section{Theoretical Framework}

The past two decades has seen a rapid development of publication of articles related to maturity (Wendler 2012). To test this hypothesis a systematic keyword search process was carried out focused on the occurrence of the word 'maturity' in abstracts of business management and engineering journals from 1990 to 2013. Four databases were used, namely: Business Source Complete, Emerald, Scopus, and Discover (a research tool of the higher education institute (HEI) of the authors). Data of the actual number of articles per database for each year were collated and used to calculate the growth rate per database and year; this is illustrated in Figure 1.

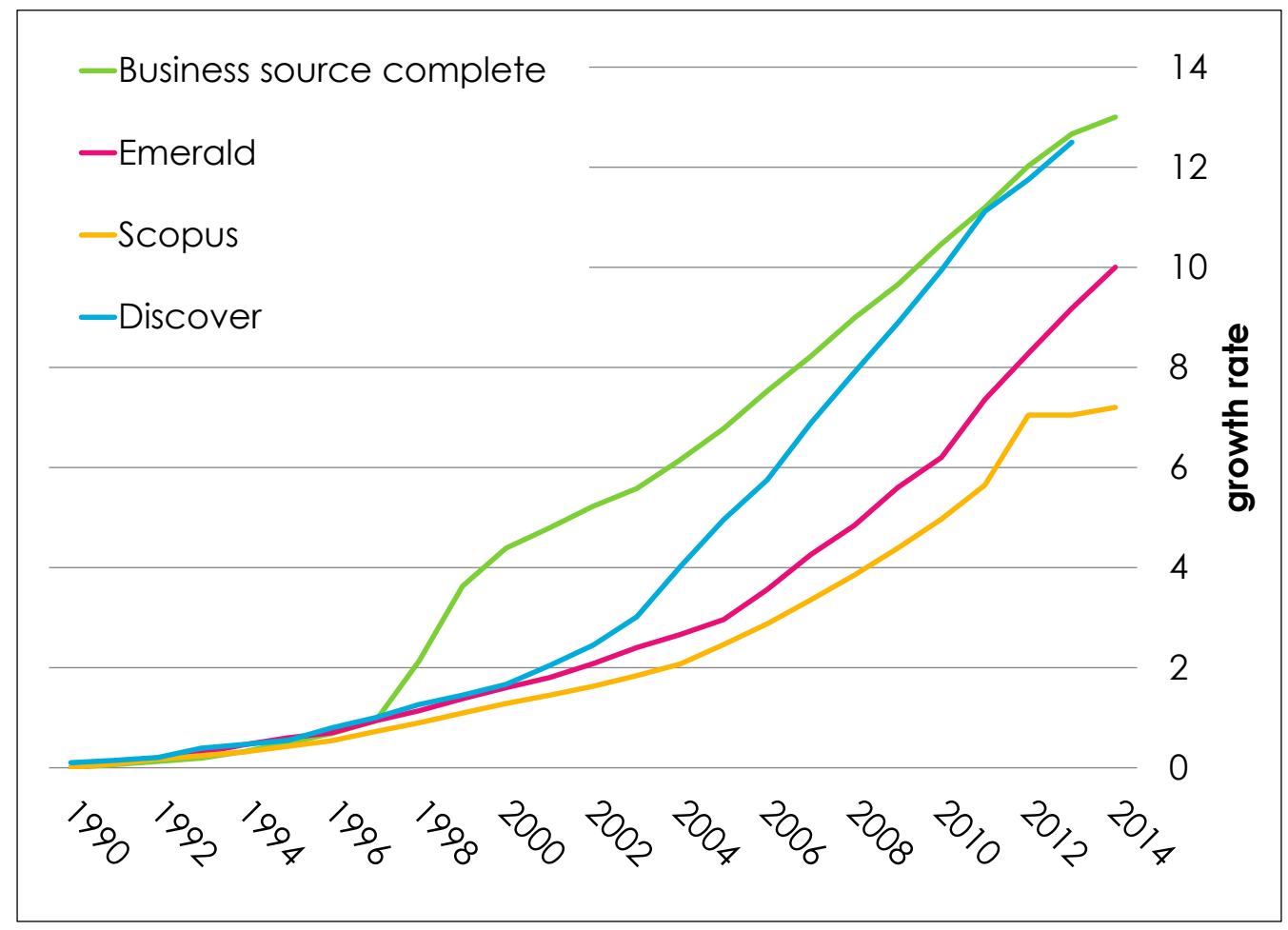

Figure1 Growth rate of maturity-related publications in a management context 
The growth rate is calculated from a 1990 baseline. Hence Growth rate $[x]=$ total number of publications [year]/ total number of publications [1990]. As shown in Figure 1 it is becoming increasingly difficult to ignore the increased attention given to the term 'maturity' within business management and engineering journals since the 1990s. Growth rates ranging from 7 up to 12.7 emphasise the spurt in growth of papers with maturity-related topics.

A second search was carried out with a focus on four journals which are either recognised or encouraged by the International Council for Research and Innovation in Building and Construction (CIB). Again a search for the word maturity within the abstract and keywords of academic articles in each journal was undertaken and the growth rate for each year and journal was calculated. The results are shown in Figure 2. The pattern is similar to that in Figure 1 but there are some distinctions. The first journal that published articles with the occurrence of the word maturity within the abstract or keyword was the CME in 1994. This journal in particular has experienced a steady growth in pertinent articles over the period, with a growth rate between 1994 and 2013 of 16. The ECAM journal had a later focus on maturity-related topics, starting in 1998, but it saw a spurt of growth in 2008.

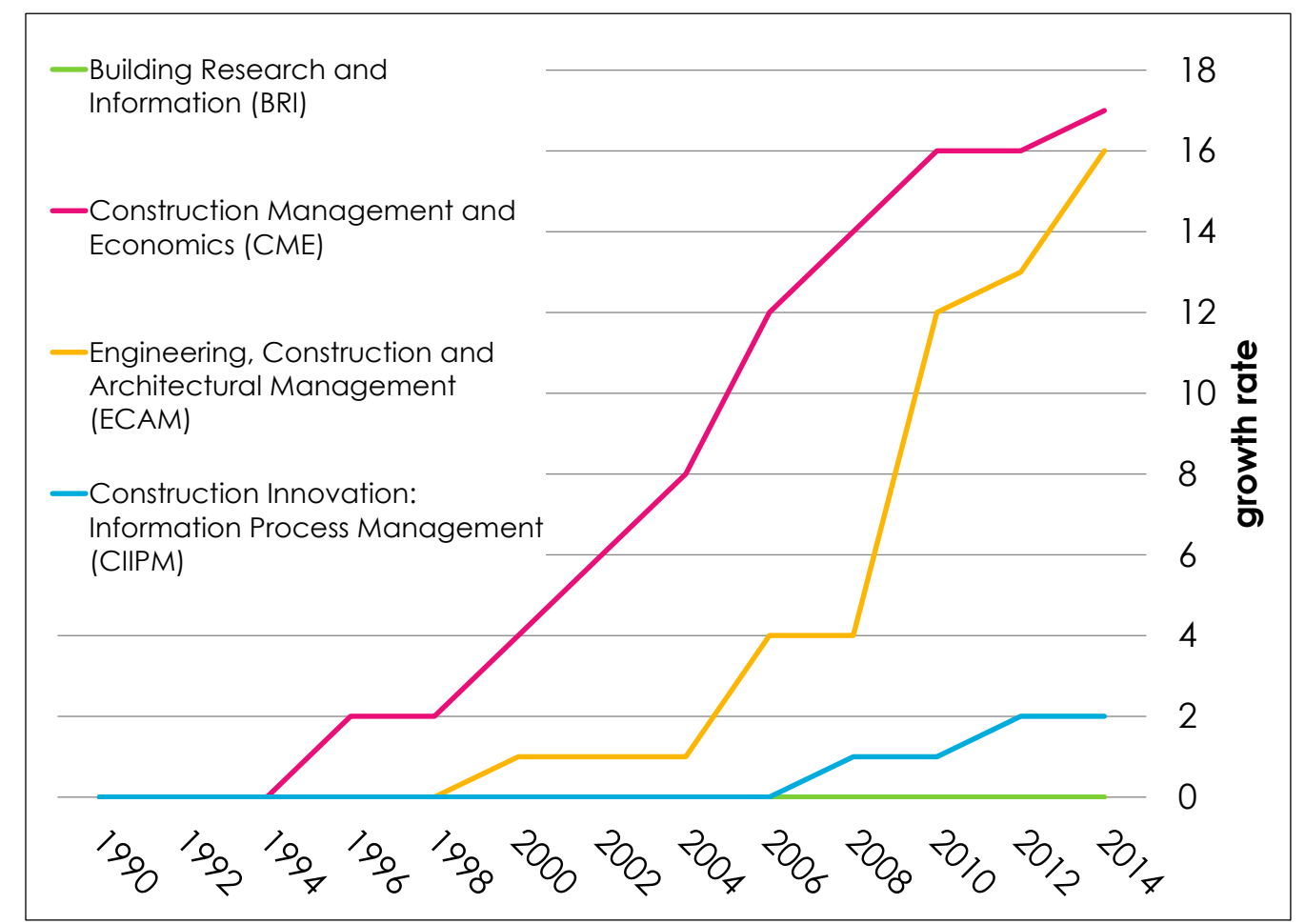

Figure 2 Growth rate of maturity-related publications in selected journals

Within a wider perspective we also calculated the growth for a number of relevant keywords in the construction-specific literature and the wider management literature. These two literature domains were distinguished by selecting the subject terms "construction" and "management" respectively in the Discover databases shown in Figure 1. The results are shown in Table 1. It is apparent from this table that the growth within the construction-related literature has not kept pace with that in the wider management literature. This corroborates findings from a recent study, which has shown that between 2009 and 201034 new MMs have been published predominately in general management journals (Wendler 2012). Yet many of the MMs now in the public domain are potentially relevant to construction contexts, with Eadie et al. (2012) identifying 53 particular MMs which are applicable. 


\begin{tabular}{|l|c|c|c|c|c|c|}
\hline \multirow{2}{*}{ Keyword } & \multicolumn{3}{|c|}{$\begin{array}{c}\text { Construction-specific } \\
\text { Literature }\end{array}$} & \multicolumn{3}{c|}{$\begin{array}{c}\text { Wider Management } \\
\text { Literature }\end{array}$} \\
\cline { 2 - 7 } & $\begin{array}{c}\text { No. } \\
\text { articles } \\
\text { in } 1990\end{array}$ & $\begin{array}{c}\text { No. } \\
\text { articles } \\
2014\end{array}$ & growth & $\begin{array}{c}\text { No. } \\
\text { articles } \\
\text { in } 1990\end{array}$ & $\begin{array}{c}\text { No. } \\
\text { articles } \\
2014\end{array}$ & growth \\
\hline Process maturity & 1 & 94 & 93 & 5 & 1691 & 1686 \\
\hline Project maturity & 0 & 145 & 145 & 3 & 785 & 782 \\
\hline Project management maturity & 0 & 62 & 62 & 2 & 604 & 602 \\
\hline Cultural maturity & 0 & 14 & 14 & 0 & 90 & 90 \\
\hline Organization maturity & 0 & 60 & 60 & 3 & 1268 & 1265 \\
\hline
\end{tabular}

Table1 Growth in the context of construction-specific literature and the wider management literature

\section{'Process', 'Project Management' and 'Project' Maturity}

One lens for viewing maturity through is in relation to the delineation of 'process', 'project management' and 'project' maturity. Process maturity describes the ability of delivering high performance in organisations (Hammer 2007). The concept of process maturity has its roots in the Total Quality Management (TQM) movement that identifies a mature process as an increasing level of performance, with high consistency in the operation of particular processes (Cooke-Davies et al. 2001). Process maturity is also pertinent to project contexts through the notion of continuously performed processes by the project organisation (Amaratunga et al. 2002, Siriwardena et al. 2005). Lockamy III and McCormack (2004), further showed that process maturity is measurable and can be illustrated through a defined lifecycle. Process maturity is therefore the extent to which an organisation is able to explicitly define, manage, measure and control a specific process (Lockamy III and McCormack 2004, Paulk et al. 1993a). The concept of a measurable lifecycle as process maturity, has been also developed and tested relative to the project management processes (Ibbs and Kwak 2000).

Project management maturity derives its understanding of 'maturity' through the recontextualising of the concept of organisational maturity (in software development processes) to project management (Cooke-Davies and Arzymanow 2003, Ibbs and Kwak 2000, Maier et al. 2012). The logic behind this is that a project needs a mature organisation and its support to be successful and effective (Richardson 2010, pp. 427). In this sense, a linked concept: organisational maturity, can be described as the application of maturity to an organisation, which is then, in relation to the degree of maturity, perfectly conditioned to achieve its objectives (Andersen and Jessen 2003). This also includes the extent to which the organisation has explicitly and consistently deployed their processes (Van Looy et al. 2011). Project maturity reflects the ability of the organisation to manage different types of projects (Phungula 2008). So maturity in a project organisation relates to how effective and efficient they are in achieving their project objectives (Andersen and Jessen 2003). Ibbs and Kwak (2000), illustrated in their study; project maturity through actions which are conceptualised by what organisations and people do. This notion can be articulated in terms of the receptiveness of an organisation (Skulmoski 2001); and furthermore, an organisation which combines operational action with competence, skills and attitudes (Andersen and Jessen 2003).

\section{'Immature' v 'Mature' Organisations}

Another useful lens through which to view the concept of maturity in management terms is to consider what distinguishes an immature organisation from a mature one. Immature organisations have no objective foundation to assess quality or to solve product or process problems (Paulk et al. 1993a, Sarshar et al. 2000). Further they are characterised by 
achieving less goals than planned; having poor quality assurance and higher actual costs compared to the estimated costs (Harmon 2004). However, it is important to note that immature organisations may occasionally deliver excellent results (Humphrey 1989) through the heroic efforts of individuals and by using approaches in a spontaneous and unplanned manner (Harmon 2004, Sarshar et al. 2000). Therefore project managers of immature organisations mainly focus on solving immediate issues and by constantly engaging in firefighting (OGC 2010).

By way of contrast, mature organisations are characterised by creating schedules for projects and keeping projects regularly on track (Harmon 2004). They have automatic behaviours, systematic processes, clear defined roles and responsibilities, clear ways of doing things and constantly achieve their planned goals with minor deviation (Harmon 2004, OGC 2010, Paulk et al. 1993a). In addition, they have a higher ability to attract and develop individual talents (resources) which perform consistently in their way of working as expected from their position (Curtis et al. 2001, Curtis et al. 2009). Hence project managers of mature organisations continuously monitor their capability, quality and customer satisfaction (OGC 2010, Paulk et al. 1993a). As an organisation matures it institutionalises its behaviour in such areas as corporate culture, practises, procedures, standards and structures (Paulk et al. 1993a).

\section{Maturity Models (MMs)}

It has been claimed that MMs are useful for organisations when they want to measure the current organisational capability or to implement a change or improvement strategy in an organised way, such as to transform their enterprise (OGC 2010). Hence MMs describe the evolution, over a defined period of time, of an organisation of people, technology, products and processes (Tapia et al. 2008, Wang et al. 2011). The most significant published MMs for the purpose of this study are shown in Table 2 below.

\section{Research Method}

The literature review above established the need to understand conceptions of MMs. Hence in order to make an empirical contribution to the body of knowledge of both MMs and LC the study explored and analysed perceptions of maturity in a LC context. The data for the analysis was collected through a sequential process involving three methods. First a group interview with seven key informants on LC, i.e. those working in the academic community and as practitioners was undertaken. The group were brought together under the auspices of the International Group of Lean Construction (IGLC). The IGLC is a well-known international network of professionals and researchers in architecture, engineering, and construction and the seven interviewees are all prominent within the IGLC. Hence it was a conscious decision to interview this group of people from this forum. The key informants were from three countries: US, UK and Brazil; with the individual breakdown being P\#1 (USA), P\#2 (UK), P\#3 (USA), P\#4 (USA), P\#5 (Brazil), P\#6 (USA), and P\#7 (USA). They were all Panel Members at the IGLC. As such they are recognised as experts in the field with extensive experience of contributing to the theory and practice of LC.

A follow up discussion with the same key informants via email was undertaken to investigate some of the issues raised in the group interview in more depth. An online discussion held via Linkedln was made available for all members of the Lean Construction Network group and the Lean Construction Institute group. In total 19 senior participants based in UK, USA, Australia, Russia, Chile and Norway participated in this study and shared their perception on some results of the group interview. The purpose of this online discussion was to validate the findings of stage 2 and 3 to the wider LC community.

The rational to use a group interview in the first stage, was the lack of construction key informants with experience in LC and MM. Hence the participants had to be introduced to 
MM at the beginning of the group interview. The presentation of the concept of MM in a LC context stimulated a group dynamic on a basic shared understanding of MM. The initial group interview undertaken lasted approximately one hour. Contemporaneous notes were taken of the comments of the key informants as a basis for the construction of detailed notes afterwards. The construction of more detailed notes took place during the follow-up discussion. To clarify the veracity of the taken notes, each of the seven key informants were sent a copy after the discussion. All interviewees confirmed that they were an accurate reflection of the group interview.

\begin{tabular}{|c|c|c|c|}
\hline Model & Developer & Description & Relevance \\
\hline $\begin{array}{l}\text { Capability } \\
\text { Maturity } \\
\text { Model } \\
\text { Integrated } \\
\text { (CMMI) }\end{array}$ & 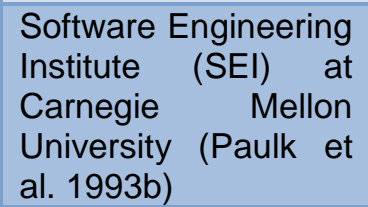 & $\begin{array}{l}\text { Consists of } 5 \text { maturity levels, key } \\
\text { process areas, best practices and } \\
\text { goals which are characterised by } \\
\text { activities and a way of behaving } \\
\text { within the organisation. }\end{array}$ & $\begin{array}{lr}\text { This model } & \text { provides } \\
\text { the most common and } \\
\text { widely } \quad \text { adopted } \\
\text { structure amongst } \\
\text { MMs. }\end{array}$ \\
\hline $\begin{array}{l}\text { Organization } \\
\text { al Project } \\
\text { Management } \\
\text { Maturity } \\
\text { Model } \\
\text { (OPM3) }\end{array}$ & $\begin{array}{l}\text { Project Management } \\
\text { Institute (PMI, US) } \\
\text { (Project Management } \\
\text { Institute 2003) }\end{array}$ & $\begin{array}{l}\text { This model integrates the PMI } \\
\text { Body of Knowledge with } \\
\text { organizational maturity and } \\
\text { addresses portfolio, program and } \\
\text { project management. It consists } \\
\text { of a list of over } 600 \text { best practices } \\
\text { and } 4 \text { stages (maturity levels). }\end{array}$ & $\begin{array}{l}\text { Shows a MM on the } \\
\text { basis of an existing } \\
\text { Body of Knowledge } \\
\text { which uses extensive } \\
\text { quantitative data to } \\
\text { determine the current } \\
\text { maturity. }\end{array}$ \\
\hline $\begin{array}{l}\text { Berkley } \\
\text { Project } \\
\text { Management } \\
\text { Process } \\
\text { Maturity } \\
\text { Model }\end{array}$ & $\begin{array}{l}\text { Dr. Williams lbbs, } \\
\text { University } \quad \text { of } \\
\text { California, Berkley } \\
\text { (US) (Kwak and lbbs } \\
\text { 2000, Kwak and lbbs } \\
\text { 2002) }\end{array}$ & $\begin{array}{l}\text { This model builds on the CMMI } \\
\text { structure and industry best } \\
\text { practices in PM. It consists of } 5 \\
\text { maturity levels, key PM } \\
\text { processes, organisation } \\
\text { characteristics and focus areas. }\end{array}$ & $\begin{array}{l}\text { This MM illustrates a } \\
\text { practical adoption with } \\
\text { several modifications } \\
\text { of the CMMI structure } \\
\text { to PM. }\end{array}$ \\
\hline $\begin{array}{l}\text { Portfolio, } \\
\text { Program and } \\
\text { Project } \\
\text { Management } \\
\text { Maturity } \\
\text { Model } \\
\text { (P3M3) }\end{array}$ & $\begin{array}{l}\text { Office of Government } \\
\text { Commerce (OGC, } \\
\text { UK) (OGC 2010) }\end{array}$ & $\begin{array}{l}\text { The P3M3 combines portfolio, } \\
\text { program and project } \\
\text { management, but it allows the } \\
\text { independent use of each or more } \\
\text { than one model. It consists of } 5 \\
\text { maturity levels, process } \\
\text { perspectives and specific } \\
\text { attributes and generic attributes. }\end{array}$ & $\begin{array}{l}\text { Again this MM } \\
\text { illustrates a different } \\
\text { practical adoption of } \\
\text { the CMMI structure to } \\
\text { PM. }\end{array}$ \\
\hline $\begin{array}{l}\text { Standardized } \\
\text { Process } \\
\text { Improvement } \\
\text { for } \\
\text { Construction } \\
\text { Enterprises } \\
\text { (SPICE) }\end{array}$ & $\begin{array}{l}\text { Centre for } \\
\text { Information in } \\
\text { Technology (CITC), } \\
\text { Construction (CITS } \\
\text { University of Salford } \\
\text { (UK) (Sarshar et al. } \\
\text { 1999) }\end{array}$ & $\begin{array}{l}\text { This } \mathrm{MM} \text { is a CMMI adaption to } \\
\text { the construction industry. It } \\
\text { comprises } 5 \text { maturity levels, key } \\
\text { processes, and process enablers. }\end{array}$ & $\begin{array}{l}\text { The SPICE is a re- } \\
\text { contextualization of the } \\
\text { CMMI to construction } \\
\text { processes which } \\
\text { shows a unique and } \\
\text { detailed adoption of } \\
\text { the CMMI to the } \\
\text { construction industry. }\end{array}$ \\
\hline
\end{tabular}

Table 2 Significant MMs for the purposes of this study

The data from this group interview and the follow up discussion were then analysed using the framework method(C; a widely used method for qualitative data analysis developed from the National Centre for Social Research (NatCen) in the 1980s (NatCen Social Research 1999). This approach has been used in previous construction management research (Baiden et al. 2006, Whittock 2002), and is derived from the thematic framework, which provides the central element of the method (Ritchie et al. 2003). The method provides a systematic and comprehensive thematic approach to ordering and synthesising the data against key issues and themes which are developed from the data (Ritchie and Spencer 2002). The framework consists of the generation of charts or matrices (often as a DIN A3 page) which organise the data in the form of distilled key topics in cells for each participant which form the subthemes of the thematic framework (Whittock 2002). The framework 
method(C comprises of six key steps (Ritchie and Spencer 2002), and its deployment is described as follows.

1. Familiarisation - by the immersion into the textual data through reading and reviewing the notes a number of times.

2. Identify descriptive categories - during the familiarisation process the thematic framework (descriptive category) is identified through recognising and note taking of important themes and sub-themes. Hence it is intended to aid an understanding of the meaning of the data through the development of the thematic framework. The output of these activities is the development of a summary theme and sub-themes from the data that capture key themes which are judged to be important to understand the conceptions of maturity and towards MMs in a LC context amongst the participants.

3. Indexing - not applicable as pilot charting (step 4) was carried out instead.

4. Pilot charting - to test whether the developed thematic framework was capable of holding all the collected data a pilot charting of examples of the textual data mapped against the framework was carried out. After a successful pilot charting a thematic framework which is appropriate to organise all the data can be derived. In this study it consisted of two sub-themes:

\section{Theme 1 Perception of maturity in Lean construction}

Sub-theme 1.1 Conceptions of maturity in a LC context

Sub-theme 1.2 Conceptions towards maturity models in a LC context.

5. Charting - this process summarises the key points of the data and provides a distilled summary of meaning organised in the framework matrix (Ritchie et al. 2003). A DIN A3 matrix with both subthemes on the top of the matrix and the seven participants on the left side were created. Judgement is important in this process to find the right balance between summarising and condensing the data in a way that retains enough contexts and essence of the comments being made i.e. not relying on verbatim parts of textual data (ibid.).

6. Investigation and interpretation - The last step of the framework method(C involves the interpretation of the data as a whole in order to define concepts, map the range and nature of the phenomena, create typologies, find associations and provide explanations of the findings (Ritchie and Spencer 2002). To facilitate this process the tool Mind Maps ${ }^{\circledR}$ was utilised, which is widely used within operational research and other management-related disciplines (Vidal 2006).

The philosophical consideration for this research can be viewed from two perspectives. The first was linked to essential requirement of investigating maturity models and LC. The second was linked to the need to select a research strategy that enabled the dissemination of MMs data from the group interview participants. The findings are presented below under the two sub-themes drawn from the analysis.

\section{Findings and Discussion}

The findings of the group interview revealed some scepticism towards MMs in a LC context. For instance questioned participant \#4 (P\#4) the existence of MM-driven improvement; stating that he 'never saw a successful MM'. Another perception was that MMs could lead to reducing LC to a toolbox consisting of certain tools and practices. $\mathrm{P} \# 2$ added to this that 'existing MMs have been criticised', with the SPICE model gaining limited traction in the 
industry. Another sceptic stated by P \#6 was that MMs could 'tranquillise' people, leading to complacency and a lack of focus. There are several possible explanations for such scepticism. For example we find in the PM literature on MMs i.e. OPM3 and Berkley's ( $\left.\mathrm{PM}^{2}\right)$ the deconstruction of PM into certain best practices derived from e. g.: PMBOK®. In comparison to the domain of PM there is no combined body of knowledge captured in a book within LC. Further it is not surprising that a concept which is discussed in many industries is not without criticism. However, much of the literature on MMs criticises the flexibility of MMs in particular if organisations undertake unusual projects at the operational level (Kujala and Artto 2000). Furthermore it is argued that 'the main weakness of many MMs is the lack of a focus on the strategic management of project-based organisations' (Kujala and Artto 2000, pp. 47). Nevertheless some participants associated MMs as valuable. So was stated by $\mathrm{P} \# 7$ that 'a MM will show the path of the LC evolution'. Another key informant pointed out that they were not saying that 'MMs have no value' whilst pointing further to Crosby's QMMG (Crosby 1979) as something that delivered positive and general boundaries within MMs.

The specific findings of both sub-themes are further presented and discussed in the next section.

\section{Sub-theme 1: $\quad$ Conceptions of maturity in the context of $L C$}

Four major topics regarding this first sub-theme were derived. As shown in Figure 3 the topics are: (1) maturity is perceived as an endpoint, (2) maturity relates to a set of tools to measure it, (3) the term maturity could be replaced by a substitute term and (4) maturity in LC should be linked to the notion of understanding and philosophy. Figure 3 also shows example quotes from the participants in each of the topic areas i.e. P\#4 is participant No.4. The next section discusses each of these four topic areas.

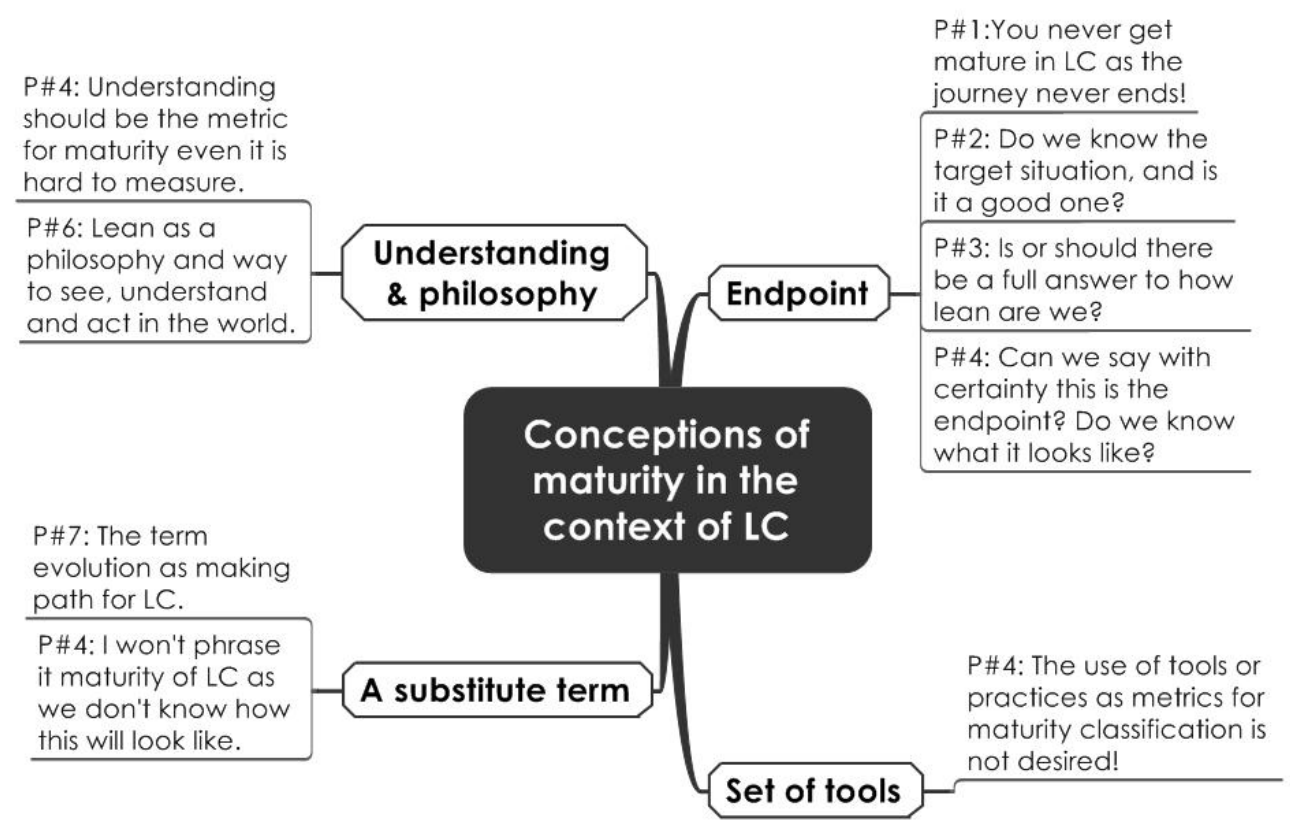

Figure 3 Conceptions of maturity

\section{Topic 1: $\quad$ Endpoint}

The first major topic 'endpoint' illustrates that the P \#1, \#2, \#3 and \#4 links the notion of maturity with a defined endpoint by using phrases like 'end of the journey', 'the target', 'target situation' and 'full answer'. This raises the issue of the usefulness of knowing or having such 
an endpoint in mind. Not only do these conceptions of the key informants indicating a potential lack of knowledge but also on answering the question: what is 'mature' in a LC context? Answering this introduces corollary questions: Is it useful to know what maturity in LC is? If yes, what does LC maturity look like? How would an organisation become more mature in LC? Is there really an identifiable endpoint in LC maturity? How Lean are we? Considering the large body of published work on maturity and maturity-related concepts, investigating the meaning of maturity in LC and trying to answer the above questions could potentially reveal new insights into both the field of MM and LC. Additionally there are already concepts of Lean maturity in other industries, such as aerospace, which are usefully applied to practice. However, the interview findings reveal a significant gap in knowledge as to what maturity in LC looks like. This is despite the fact that there has been work undertaken regarding the maturity in LC from industry policy makers such as the European Construction Institute (ECl) and the Highway Agency (HA) in UK. The latter of these two organisations re-contextualised the LESAT to a Highway Agency Lean Maturity Assessment Toolkit (HALMAT), with the aim being to determine the Leanness of the supply chain in relation to the objectives of the HA (Highways Agency 2010).

Given the emphasis by authors such as Caffyn (1999) on the importance of approaches to assess the organisational transformation and further consider the fact that implementing LC is a transformation (also often stated as journey) of an organisation (Mossman 2009, Sage et al. 2012, Zimina et al. 2012), the transformation can be seen as the movement towards maturity. However, as maturity is conceptualised as the movement towards an ideal point (Hogan and Roberts 2004) and an organisation is mature when it is perfectly conditioned to reach its objectives and goals continuously, in the real world it would be impossible to find a fully mature organisation (Andersen and Jessen 2003). This suggests that, contrary to the view of some of the participants, being mature is not a tangible end-point. Rather, it is more appropriate perhaps to illustrate the 'endpoint' of being mature in LC as an idealised vision that one is constantly striving to achieve. This vision is similar then to the one used by what is arguably one of the most mature companies in terms of Lean: Toyota. Toyota strive to realise their vision of zero defects, 100 per cent value with the lowest costs and continuous flow production (Rother 2010). The vision of an ideal endpoint provides a clear direction towards maturity, although it is never actually reached (Andersen and Jessen 2003, Rother 2010) Being mature in LC can be seen as interchangeable with a vision or ideal as a goal of a Lean transformation within an organisation which is to be pursued (Zimina et al. 2012). The comment of $\mathrm{P} \# 1$ reflects this analogy: 'the Lean journey never ends and you don't get mature in $L C$ '.

Another analogy is appropriate and that is with the concept of human maturity. The human maturity process is a circle without an end; regardless of where we go, we will get new experiences (Sams 1999, p. 7). So humans never stop learning and becoming more mature as they interact with their environment. As articulated by the P \#2; ' $L C$ is still developing and could involve something else in the next 5 years!' Additional comments from $\mathrm{P} \# 2$ made explicit the link between the concept of maturity in business and that of human maturity: 'We as humans recognise that the more we learn, the more we discover that we have to learn'. So learning is an important process in relation to LC maturity.

The supporting data in the online discussion confirmed the perception of maturity as a final state or goal. With the additional consensus view that the term 'maturation' is appropriate to use in this context as one that describes the process of maturing towards a goal or vision. Yet all these views do not align with the current literature on the topic. The online discussion revealed further doubts as to whether there is currently a completely satisfactory answer to the question 'how mature are we?'; which provides added impetus for the development of a MM. 


\section{Topic 2: $\quad$ Set of tools}

The second major topic derived was that maturity in LC can be measured by a set of tools. This can be related to published PM MMs, such us the OPM3 and the Berkley $\left(\mathrm{PM}^{2}\right)$, where maturity is measured with best practices and tools from the PMBOK® (Cooke-Davies 2004). Nevertheless the counter-argument that the metrics for LC maturity should be based on a deeper understanding of the topic, rather than just the tools and practices, is a moot point which ought not to be overlooked. It must be recognised that there is a need for research to explore which metrics are more or less appropriate for LC and how LC can be conceptualised through these metrics.

\section{Topic 3: $\quad$ A substitute term}

The third topic, the use of a substitute term was neatly articulated by $P$ \#4, who stated: ' wouldn't phrase it 'maturity' of LC'. The theme was taken further by $\mathrm{P} \# 7$, who suggested using the term 'evolution'. Taking into account the existing terminology of Lean 'maturity' in an aerospace context (LESAT), the work of the policy makers regarding LC 'maturity' (HALMAT-UK Highway Agency and LCTF of the ECI) and the increased volume of work using the term 'maturity' in the academic literature raises questions as to the desirability of adopting any substitute term for the domain of LC.

The appropriateness of the term 'maturity' was also confirmed by a large part of the supporting data. Eleven out of the 19 individuals who participated in the online discussion regarded it as an appropriate term for LC - though 3 individuals were in agreement with the key informants in questioning the use of the term. Its appropriateness as a term was demonstrated by comments like: 'the concept of maturity is a commonly used in management terms' and '[the term maturity was] especially widely used in UK within management processes or Lean self-assessment kits. It was also stressed that the term maturity has to be used 'in the interest of comprehension' and that 'maturity is fully applicable to $L C$.

\section{Topic 4: $\quad$ Understanding and philosophy}

The final topic relates to the level of understanding of LC and whether a LC philosophy is followed; though in the words of P \#4 this is something that is 'hard to measure'.

An interesting attempt towards understanding LC maturity is evident from the supporting data derived from the Linkedln discussions. Several ideas were put forward in terms of possible relationships with maturity i.e. it could be related to; experience, open considerations, concise decision-making, change in culture, efficiency, knowledge, productivity, learning, a state of mind, of a certain attitude or approach to business. An observation from one of the Linkedln discussions that is worthy of further consideration was that, perhaps 'the start of $L C$ being integrated with the existing project delivery methods is in itself a sign of maturity'.

\section{Sub-theme 2: $\quad$ Conceptions towards Maturity Models in the context of LC}

The second sub-theme in the thematic framework was also broken down into four major topics, as shown in Figure 4. These are: (1) MMs are a kind of target situation; (2) a MM for LC requires a distinctive focus; (3) MMs involve a standard structure; and (4) MMs show the next level. The next section discusses each of these in turn. 


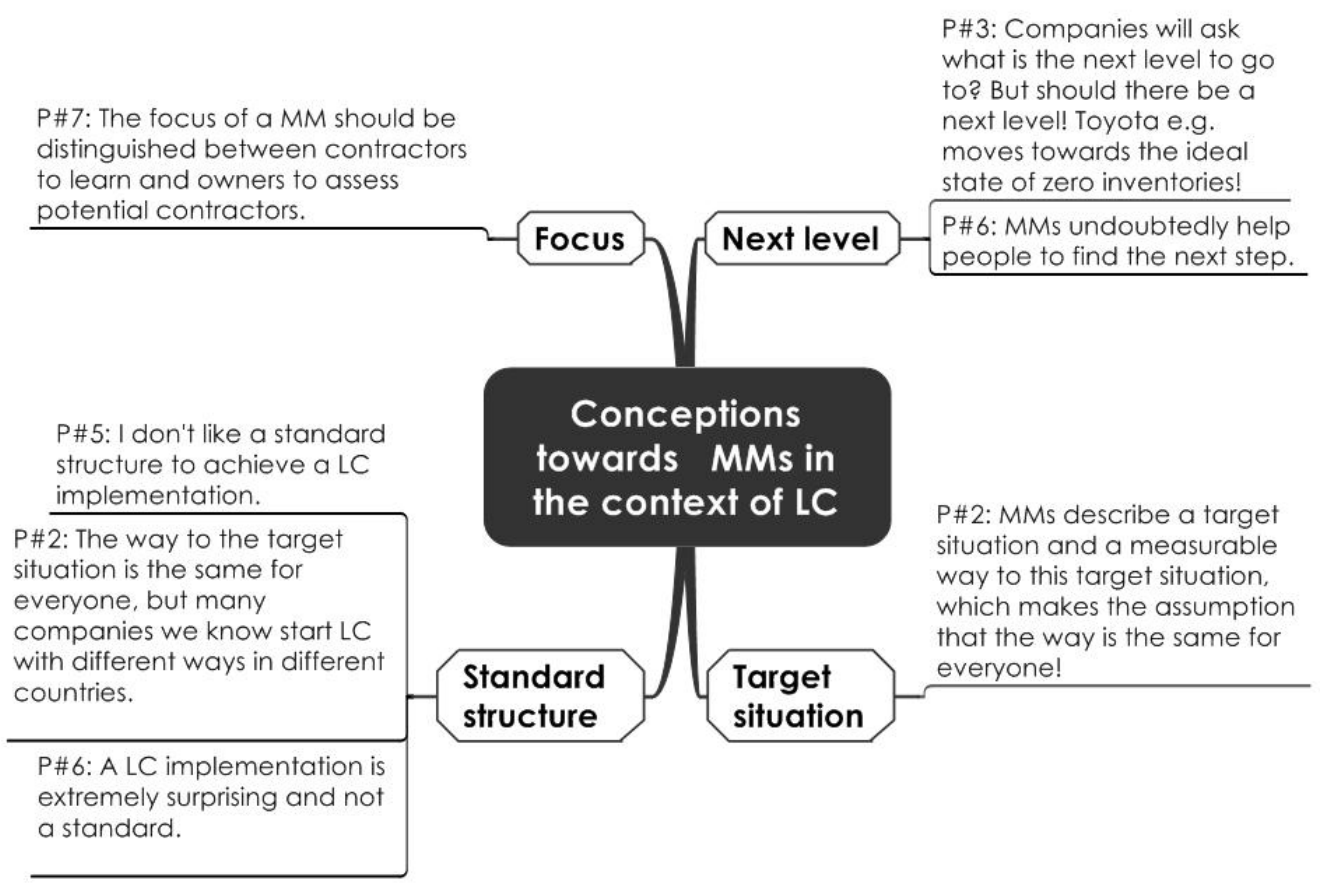

Figure 4 Concepts of maturity models

\section{Topic 1: $\quad$ Target situation}

The first area of discussion sees MMs as 'a kind of target situation and a way to that, which will be measured through the model' ( $\mathrm{P} \# 2$ ). It was further implied that the route to this target situation in a MM is the same for everyone. This differs to the extant literature, for instance the UK Government report (OGC 2010), which argues that a MM supports organisations to implement their own unique change or improvement strategy in a managed way. Furthermore, MMs like the CMMI or the OPM3 does not prescribe how to improve specific areas, rather they point out the priority for improvement actions which may be different for each individual (CMMI Product Team 2010, Project Management Institute 2003).

\section{Topic 2: $\quad$ Focus}

One aspect of the data concerned what would be the focus of a possible MM in the context of LC. For example it was argued by $\mathrm{P} \# 7$ that 'the focus of a MM within LC should be distinguished'. The sense here is that it must be clear if the focus is on the clients - using it as a form of assessment tool to evaluate contractors, or used by contractors as an improvement tool within their organisations. It is worth noting in this respect that several MMs in other industries are used in both situations.

\section{Topic 3: $\quad$ Standard structure}

The attitude that MMs would deliver an undesired standardised structure for a LC implementation was articulated by P\#5 who said 'I don't like a standard structure to achieve a LC implementation'. This view was countered by the experiences of $\mathrm{P} \# 2$ and \#6 regarding the implementation process of LC. $\mathrm{P}$ \#2 stated that 'many companies start with Last Planner® and companies in UK or Brazil start with different things' and $\mathrm{P}$ \#6 concurred, pointing out that they found the 'implementation of [LC] extremely varied and not a standard'. However, it is worth considering more closely what kind of standard an MM would establish. MMs provide a common and shared language and understanding (Klimko 2001) i.e. in PM. Although somewhat dependent on the specific MM, in general they do not tell the organisation how and with what standard they should improve but, rather, point out where to improve; because most MMs are non-prescriptive. 


\section{Topic 4: $\quad$ Next level}

Perceptions about a progression measured in maturity levels were made in the context of the Last Planner ${ }^{\circledR}$ System; with P \#3 illustrating the point by stating: 'I know companies will ask what the next level to go to is, but should there be a next level! Since Toyota e.g. moves towards the ideal state of zero inventories.' Hence a conception is that practitioners are interested in further steps to take within a LC transformation; however, a moot point is whether there is a next step which is the same for all? This links to the earlier discussion of a target situation (Topic: 1). Emphasising the power of MMs it was also stated (P \#6) that MMs would undoubtedly help people to identify the next step. However, the scepticism about the ability to clearly identify boundaries, discussed in the previous section, stress the crucial task of defining maturity levels.

\section{Conclusions}

This paper has given an account of and the reasons for the widespread use of MMs in several industries. This study set out to determine the role of MMs in relation to LC, and to explore what we need to understand about maturity, and the conceptions of those closely involved in the construction industry about MMs in a LC context. A number of noteworthy issues have been identified that have not been discussed in the Lean literature. It has been shown that perceptions regarding the term 'maturity' of the key informants are diverse and could lead to potential misconceptions and concerns. Yet the findings suggest that maturity in LC can be generally perceived as the path of LC evolution. It was also revealed that metrics such as tools are regarded as inappropriate for assessing maturity in LC. It was further shown that the participants are rather sceptical about using the concept of maturity for LC. It is worth highlighting that, these perceptions are at odds with the literature in other management domains such as PM, and process management. Hence it is most likely that a lack of engagement with the concept of maturity by the key informants and the limited attention of MMs within the LC literature are the underlying reasons for such a finding. Despite the concerns and misconceptions about the term maturity and MMs there is certainly a growing body of literature on the subject of maturity; confirming that it is indeed a topic to which the research community could usefully paying increased attention to.

The results of this study indicate that there are no major constraints on MMs being contextualized to LC. Hence, there is the potential through a synergy of the concepts of MM and LC to deliver similar benefits as those reported when MMs are used in other management domains, for instance in providing effective support of ongoing transformations in organisations (Perkins et al. 2010). However as revealed in this study, it seems that the development of any MM for LC requires appropriate metrics which are coherent with Lean's underpinning philosophy, and which capture the behaviour, understanding and the outcomes of a typical organisation. The results also highlight that being mature is not an endpoint which will be achieved by everyone; rather it is a desired target that is forever moving.

It is necessary to note a limitation of this study, which is that the respondents might have a particular view on this investigation through their connection to the IGLC and other groups. An issue that was not addressed in this study was whether MM professionals are included in the sample. Therefore a larger and more random sample comprising of group discussion with key informants from both sides is suggested to generalise and validate the findings reported in this paper.

\section{Recommendations for Further Research}

As the concept of maturity has the potential to make a significant contribution to helping an organisation direct its change initiatives, further research on maturity in the context of LC is required. Linked to this is research into the appropriate metrics of LC maturity. Another avenue for further research is on whether the focus of LC MMs should be on the customers and clients, so that they can assess their contractor's maturity, or on the contractors and 
projects, in order to drive and prioritise internal improvement. Finally more work will need to be done to determine the relevance of the difference between MMs for LC within permanent operations-focused organisations and temporary (project) organisations.

\section{References}

Amaratunga, D., M., S. and D., B. (2002) 'Process improvement in facilities management: the SPICE approach', Business Process Management Journa, 8 (4), 318-37.

Andersen, E.S. and Jessen, S.A. (2003) 'Project maturity in organisations', International Journal of Project Management, 21 (6), 457-61.

Baiden, B.K., Price, A.D.F. and Dainty, A.R.J. (2006) 'The extent of team integration within construction projects', International Journal of Project Management, 24 (1), 13-23.

Caffyn, S. (1999) 'Development of a continuous improvement self-assessment tool', International Journal of Operations \& Production Management, 19 (11), 1138-53.

CMMI Product Team (2010) CMMI for services, version 1.3, CMU/SEI-2010-TR-034, Pittsburgh: Software Engineering Institute.

Cooke-Davies, T.J. (2004) 'Measurement of organizational maturity', In: Slevin, D P, Cleland, D I and Pinto, J K (Ed.), Innovations-Project Management Research 2004, Newtown Square: PMI, 211-28.

Cooke-Davies, T.J. and Arzymanow, A. (2003) 'The maturity of project management in different industries: An investigation into variations between project management models', International Journal of Project Management, 21 (6), 471-8.

Cooke-Davies, T.J., Schlichter, J. and Bredillet, C. (2001) 'Beyond the PMBOK guide', In: Project Management Institute (Ed.), Annual Project Management Institute Seminar \& Symposium, 7-10 November, Nashvill, USA. PMI, Vol. 32 ${ }^{\text {th }}$.

Crosby, P.B. (1979) Quality is free : The art of making quality certain, New York: McGrawHill.

Curtis, B., Hefley, W.E. and Miller, S.A. (2001) People Capability Maturity Model (P-CMM), Pittsburgh: Software Engineering Institute.

Curtis, B., Hefley, B. and Miller, S. (2009) People Capability Maturity Model (P-CMM) Version 2.0, Pittsburgh: Software Engineering Institute.

Eadie, R., Perera, S. and Heaney, G. (2012) 'Capturing maturity of ICT applications in construction processes', Journal of Financial Management of Property \& Construction, 17 (2), 176-94.

Green, S.D., Harty, C., Elmualim, A.A., Larsen, G.D. and Kao, C.C. (2008) 'On the discourse of construction competitiveness', Building Research \& Information, 36 (5), 426-35.

Hammer, M. (2007) 'The process audit', Harvard Business Review, 85 (1), 11-123.

Harmon, P. (2004) 'Evaluating an organisation's business process maturity', Business Process Trends, 2 (3), 1-11.

Highways Agency (2010) Highways Agency Lean Maturity Assessment Toolkit (HALMAT), PR 145/10, Birmingham, UK: Highways Agency Publications.

Hogan, R. and Roberts, B.W. (2004) 'A socioanalytic model of maturity', Journal of Career Assessment, 12 (2), 207-17.

Huat, T.P. and Low, S.P. (1994) 'The fuzzy industry maturity grid (FIMG) and its application to the Singapore construction industry', Construction Management and Economics, 12 (2), 125-38.

Humphrey, W.S. (1989) Managing the software process, Boston: Addison-Wesley.

lbbs, C.W. and Kwak, Y.H. (2000) 'Assessing project management maturity', Project Management Journal, 31 (1), 32-43. 
Klimko, G. (Year) 'Knowledge management and maturity models: Building common understanding', In: Remenyi, D (Ed.), Proceedings of the 2nd European Conference on Knowledge Management (ECKM), Bled, Slovenia. Bled School of Management, 269-78.

Koskela, L. and Ballard, G. (2012) 'Is production outside management?', Building Research \& Information, 40 (6), 724-37.

Kujala, J. and Artto, K. (2000) 'Criteria for project performance in business context', International Project Management Journal, 6 (1), 46-53.

Kwak, Y.H. and lbbs, C.W. (Year) 'The Berkeley project management process maturity model: Measuring the value of project management', In Proceedings of the 2000 IEEE Engineering Management Society, 13-15 August, Albuquerque, NM, USA. IEEE1-5.

Kwak, Y.H. and Ibbs, C.W. (2002) 'Project management process maturity (PM) model', Journal of Management in Engineering, 18 (1), 150-5.

Lockamy III, A. and McCormack, K. (2004) 'The development of a supply chain management process maturity model using the concepts of business process orientation', Supply Chain Management: An International Journal, 9 (4), 272-8.

Maier, A.M., Moultrie, J. and Clarkson, P.J. (2012) 'Assessing organizational capabilities: Reviewing and guiding the development of maturity grids', IEEE Transactions on Engineering Management, 59 (1), 138-59.

McGrath-Champ, S. and Rosewarne, S. (2009) 'Organizational change in Australian building and construction: Rethinking a unilinear 'leaning' discourse', Construction Management and Economics, 27 (11), 1111-28.

Mossman, A. (2009) 'Why isnt't the UK construction industiry going Lean with gusto?', Lean Construction Journal, 5 (1), 24-36.

NatCen Social Research (cited 2013) The Framework method for qualitative data analysis, [Available online from http://www.natcen.ac.uk/our-expertise/framework.]

Nesensohn, C., Demir, S.T. and Bryde, D.J. (2013) 'Developing the True North route map as a navigational compass in a construction project management organisation', Lean Construction Journal, 2013 (1), 1-18.

OGC, O.o.G.C. (2010) 'Portfolio, programme and project management maturity model (P3M3®): Introduction and guide to P3M3®', In: Office of Government Commerce, Ed., Norwich, UK: Cabinet Office of Rosebery Court, 1-17.

Paulk, M.C., Bill, C., Chrissis, M.B. and Weber, C.V. (1993a) Capability maturity model for software 0471028959, Pittsburgh: Software Engineering Institute.

Paulk, M.C., Curtis, B., Chrissis, M.B. and Weber, C.V. (1993b) 'Capability maturity model, version 1.1', Software, IEEE, 10 (4), 18-27.

Pennypacker, J.S. (2005) Project portfolio management maturity model, Pennsylvania, USA: Center for Business Practices.

Perkins, L.N., Abdimomunova, L., Valerdi, R., Shields, T. and Nightingale, D. (2010) 'Insights from enterprise assessment: How to analyze LESAT results for enterprise transformation', Information Knowledge Systems Management, 9 (3/4), 153-74.

Phungula, M.G.P.G. (2008) Review and Analysis of Organisational Project Management Maturity Of The South African Government Departments involved in Public Private Partnership (PPP) Projects, University of South Africa.

Project Management Institute (2003) Organizational Project Management Maturity Model OPM3 Knowledge Foundation, 2nd ed,ed. Vol. second edition, Pennsylvania, USA: PMI.

Richardson, G.L. (2010) Project management theory and practice, Boston: Auerbach Pub./CRC Press.

Ritchie, J. and Spencer, L. (2002) 'Qualitative data analysis for applied policy research', In: Bryman, A and Burgess, R G (Ed.), Analzing qualitative data, London: Routledge, 173-94. 
Ritchie, J., Spencer, L. and O'Connor, W. (2003) 'Carrying out qualitative analysis, In: Ritchie, J and Lewis, J (Ed.), Qualitative research practice: A guide for social science students and researchers, London: Sage, 219-62.

Rother, M. (2010) TOYOTA KATA: Management people for improvement, adaptiveness, and superior results, New York: McGraw-Hill.

Sage, D., Dainty, A. and Brookes, N. (2012) 'A 'strategy-as-practice' exploration of Lean construction strategizing', Building Research \& Information, 40 (2), 221-30.

Sams, J. (1999) Dancing the dream: The seven sacred paths of human transformation, Vol. 1, San Francisco: HarperCollins.

Sarhan, S. and Fox, A. (2013) 'Performance measurement in the UK construction industry and its role in supporting the application of lean construction concepts', Australasian Journal of Construction Economics and Building, 13 (1), 23-35.

Sarshar, M., Haigh, R., Finnemore, M., Aouad, G., Barrett, P., Baldry, D. and Sexton, M. (1999) 'SPICE: Is a capability maturity model applicable in the construction industry', In: Lacasse, M A and Vanier, D J (Ed.), International Conference on Durability of Building Materials and Components, 30 May, Vancouver, Canada. National Research Council Canada, Vol. 8th, 2836-43.

Sarshar, M., Haigh, R., Finnemore, M., Aouad, G., Barrett, P., Baldry, D. and Sexton, M. (2000) 'SPICE: A business process diagnostics tool for construction projects', Engineering Construction and Architectural Management", 7 (3), 241-50.

Siriwardena, M.L., Kagioglou, M., Jeong, K.S., Haigh, R. and Amaratunga, D. (Year) 'SPICE 3: Facilitating organisational process improvement through good practice sharing', In Salford Centre for Research and Innovation (SCRI) 2nd International Symposium, University of Salford, Greater Manchester. University of Salford Manchester, 434-48.

Skulmoski, G. (2001) 'Project maturity and competence interface', Cost Engineering, 43 (6), 11-8.

Tapia, R.S., Daneva, M., van Eck, P. and Wieringa, R. (Year) 'Towards a business-IT aligned maturity model for collaborative networked organizations', In "12th Enterprise Distributed Object Computing Conference Workshops, 16-16 September, 276-87.

Van Looy, A., De Backer, M. and Poels, G. (2011) 'Defining business process maturity. A journey towards excellence', Total Quality Management \& Business Excellence, 22 (11), 1119-37.

Vidal, R.V.V. (2006) 'Chuck Frey, power tips and strategies for mind mapping software, learn how to think better, improve your productivity and communicate with greater impact!', European Journal of Operational Research“, 174 (2), 1348-9.

Wang, J., Xiao, J., Li, Q. and Li, K. (Year) 'Knowledge management maturity models: A systemic comparison', In Proceedings - 2011 4th International Conference on Information Management, Innovation Management and Industrial Engineering, ICIII 2011, 26-27 November, Shenzhen, China, Vol. 3, 606-9.

Wendler, R. (2012) 'The maturity of maturity model research: A systematic mapping study', Information and software technology, 54 (12), 1317-39.

Whittock, M. (2002) 'Women's experiences of non-traditional employment: Is gender equality in this area a possibility?', Construction Management and Economics, 20 (5), 449-56.

Zimina, D., Ballard, G. and Pasquire, C. (2012) 'Target value design: using collaboration and a lean approach to reduce construction cost', Construction Management and Economics, 30 (5), 383-98. 